\title{
Knowledge Extraction on Reducing the Number of Students Using Explore, Elaborate and Execute Techniques
}

\author{
Juvinal Ximenes Guterres, Ade Iriani, Hindriyanto Dwi Purnomo \\ Information Systems Masters Program, Faculty of Information Technology \\ Universitas Kristen Satya Wacana Salatiga \\ Central Java \\ *guterresmenex@gmail.com
}

\begin{abstract}
The decline in the number of students at East Timor's private universities can create new problems. This will be a burden for universities and other private institutes to develop. The financial and financing components are the factors that determine the implementation of teaching and learning activities that are used, among others, for the cost of facilities and teaching equipment. This study aims to extract knowledge of the decline in the number of students that occur every year at UNITAL. The method used is knowledge capture with Explore, Elaborate, and Execute techniques. Data collection techniques carried out by observation, interviews, documentation and questionnaires. Explore techniques to investigate results data, observations, interviews, documentation and questionnaires related to the reduction in the number of students arrested in the form of causes and effects of problems, then elaborate techniques describe interview, observation, brainstorming, and documentation data. The execute process is the stage of executing data from knowledge capture techniques based on explore and elaborate techniques and then produces a tacit and explicit knowledge from the actors or actors. The results obtained from this research are able to identify that the decline in students is caused by the main factors, namely, the quality of human resources consisting of lecturers, staff and technicians, service quality, facilities and infrastructure, buildings, classrooms, laboratory facilities, libraries and UNITAL academic information systems. Externally, there is a lack of cooperation with universities, both domestic and foreign, promotion to the public both directly and through social media. The results of knowledge capture is wealth that can be stored in a repository to be shared to help the processing of knowledge with the help of Information Technology.
\end{abstract}

Keyword:Knowledge Capture; Explore; Elaborate and Execute; knowledge management; Student Decline.

\section{Preliminary}

The education sector has a very important role to support the development of a country because it is a place for the creation of creative and innovative human resources, which will contribute to the progress of a country both now and in the future, essentially every college is an organization where knowledge created and can be used continuously. With routine activities to serve the interests of students, parents, lecturers, employees and community users of graduates [1].

Democratic Republic of Timor Leste (RDTL), the Government was formed in 2002. The Government of Timor-Leste through the ministry of education continues to strive hard to improve the quality of human resources. In addition to the construction of physical facilities and infrastructure, human resource development continues through the process of providing education. This is a clear evidence that after declaring independence unilaterally for 17 years, there are 15 tertiary institutions, both public and private. With the increase in the number of tertiary institutions in Timor-Leste it will provide more opportunities for the community to choose tertiary institutions according to their choices and economic conditions.

East Timor Oriental University (UNITAL) is one of the private universities that always pays attention to all learning processes and quality in service to consumers, namely students. Quality of service becomes a very important role for the continuation of an educational institution, for the achievement of student satisfaction and loyalty. Steps that need to be taken by educational institutions to improve these services is to optimize the ability of human resources and improve facilities and infrastructure that support the smoothness of educational services [2]. To realize professional education and training, it takes a solid commitment among all academic community members by mutually contributing by all management, 
lecturers, staff and students to follow the rules that have been set together. The high number of students must be balanced with good service, synchronization of academic regulations and facilities and infrastructure is needed to strengthen the commitment of all stakeholders to carry out and evaluate their respective activities.

Services provided to students are the top priority in providing quality academic services capable of providing student satisfaction. It also produces quality services so that students can evaluate the services they receive. Both parties have a reciprocal relationship so that each party gets the same satisfaction.

Services to students as the most important element in educational institutions that need to be listened to, whether the service is in line with expectations or not because the quality of services provided to students needs to be evaluated regularly. Also provided facilities in accordance with the needs of students in order to know what is actually expected, what satisfaction is felt by students to be able to increase their loyalty to the institution. High loyalty will reflect the behavior in order to maintain the good name of the institution during the lecture process.

To produce high-quality student graduates, it is inseparable from high-quality academic services, good services can be supported by infrastructure that provides security and comfort for students during the learning process, where human resources are lecturers, guardians, administrative staff and technicians . [3]

Based on interviews and observations conducted on the leadership and related parties, it is found that there has been a decline in the number of students in the last four years, a decrease in the number of students occurring for prospective new students who register and active students, the temporary hypothesis that the cause of the decline in students is a big factor (brand image) UNITAL is damaged in the community, lack of facilities and infrastructure, curriculum offered, non-strategic location factors, lack of good service to students. UNITAL student data are shown in tables 1 and 2 .

The data above shows the number of new students found in each faculty during 2014-2018. From this data the faculty of education is the faculty that has the most number of students compared to 7 other faculties. However, every year there is always a decrease in prospective new students who register, from the last four years continuously and the decline is also experienced by all faculties. Table 2 shows data on the number of new students at UNITAL universities.

Table. 1 UNITAL New Student Data 2014/2015 -2017/2018

\begin{tabular}{|c|c|c|c|c|c|c|c|c|c|}
\hline \multirow{3}{*}{\multicolumn{2}{|c|}{ School year }} & \multicolumn{8}{|c|}{ Faculty } \\
\hline & & $\mathrm{S} 1$ & S1 & S1 & S1 & S1 & $\mathrm{S} 1$ & S1 & $\mathrm{S} 1$ \\
\hline & & Economics & Agriculture & Law & Political & Education & Technique & Health & Mining \\
\hline \multirow{4}{*}{$\begin{array}{c}2014 / \\
2015\end{array}$} & Interest & 1100 & 1000 & 500 & 480 & 1400 & 1200 & 1000 & 900 \\
\hline & Be accepted & 1050 & 900 & 500 & 480 & 1350 & 1140 & 550 & 880 \\
\hline & Rejected & 50 & 40 & 0 & 0 & 50 & 60 & 450 & 200 \\
\hline & Re-registration & 1030 & 855 & 500 & 450 & 1350 & 1135 & 550 & 880 \\
\hline \multirow{4}{*}{$\begin{array}{c}2015 / \\
2016\end{array}$} & Interest & 1000 & 450 & 210 & 170 & 790 & 400 & 800 & 400 \\
\hline & Be accepted & 800 & 450 & 210 & 170 & 790 & 400 & 500 & 400 \\
\hline & Rejected & 10 & 0 & 0 & 0 & 0 & 11 & 300 & 0 \\
\hline & Re-registration & 700 & 400 & 200 & 150 & 600 & 355 & 450 & 370 \\
\hline \multirow{4}{*}{$\begin{array}{c}2016 / \\
2017\end{array}$} & Interest & 500 & 330 & 210 & 110 & 466 & 300 & 400 & 370 \\
\hline & Be accepted & 500 & 330 & 210 & 110 & 466 & 300 & 350 & 370 \\
\hline & Rejected & 0 & 0 & 0 & 0 & 0 & 0 & 50 & 0 \\
\hline & Re-registration & 400 & 260 & 200 & 99 & 400 & 288 & 350 & 350 \\
\hline \multirow{4}{*}{$\begin{array}{l}2017 \\
/ 2018\end{array}$} & Interest & 400 & 199 & 100 & 76 & 250 & 299 & 350 & 277 \\
\hline & Be accepted & 400 & 199 & 100 & 76 & 250 & 299 & 320 & 277 \\
\hline & Rejected & 0 & 0 & 0 & 0 & 0 & 0 & 30 & 0 \\
\hline & Re-registration & 270 & 155 & 88 & 66 & 250 & 255 & 320 & 268 \\
\hline
\end{tabular}


Table 2. New Student Data on UNITAL Programs from 2014/2015 - 2017/2018

\begin{tabular}{|c|c|c|c|c|c|c|c|c|}
\hline \multirow[b]{3}{*}{ School year } & \multicolumn{8}{|c|}{ Faculty } \\
\hline & \multicolumn{2}{|c|}{ Economics } & \multicolumn{2}{|c|}{ Agriculture } & \multicolumn{2}{|r|}{ Law } & \multicolumn{2}{|c|}{ Political } \\
\hline & $\begin{array}{c}\text { Be } \\
\text { accepted }\end{array}$ & $\begin{array}{c}\text { Re- } \\
\text { registration }\end{array}$ & $\begin{array}{c}\text { Be } \\
\text { accepted }\end{array}$ & $\begin{array}{c}\text { Re- } \\
\text { registration }\end{array}$ & $\begin{array}{c}\text { Be } \\
\text { accepted }\end{array}$ & Re-registration & $\begin{array}{c}\mathrm{Be} \\
\text { accepted }\end{array}$ & $\begin{array}{c}\text { Re- } \\
\text { registration }\end{array}$ \\
\hline $2014 / 2015$ & 1050 & 1030 & 900 & 855 & 500 & 500 & 480 & 450 \\
\hline $2015 / 2016$ & 800 & 700 & 450 & 400 & 210 & 200 & 170 & 150 \\
\hline $2016 / 2017$ & 500 & 400 & 330 & 260 & 210 & 200 & 110 & 99 \\
\hline $2017 / 2018$ & 400 & 270 & 199 & 155 & 100 & 88 & 76 & 66 \\
\hline \multirow{3}{*}{$\begin{array}{c}\text { Tahun } \\
\text { Ajarang }\end{array}$} & \multicolumn{8}{|c|}{ Fakultas } \\
\hline & \multicolumn{2}{|c|}{ Education } & \multicolumn{2}{|c|}{ Technique } & \multicolumn{2}{|c|}{ Health } & \multicolumn{2}{|c|}{ Mining } \\
\hline & $\begin{array}{c}\text { Be } \\
\text { accepted }\end{array}$ & $\begin{array}{c}\text { Re- } \\
\text { registration }\end{array}$ & $\begin{array}{c}\text { Be } \\
\text { accepted }\end{array}$ & $\begin{array}{c}\text { Re- } \\
\text { registration }\end{array}$ & $\begin{array}{c}\text { Be } \\
\text { accepted }\end{array}$ & Re-registration & $\begin{array}{c}\text { Be } \\
\text { accepted }\end{array}$ & $\begin{array}{c}\text { Re- } \\
\text { registration }\end{array}$ \\
\hline $2014 / 2015$ & 1350 & 1350 & 1140 & 1135 & 550 & 550 & 880 & 880 \\
\hline $2015 / 2016$ & 790 & 600 & 400 & 355 & 500 & 450 & 400 & 370 \\
\hline $2016 / 2017$ & 466 & 400 & 300 & 288 & 350 & 350 & 370 & 350 \\
\hline $2017 / 2018$ & 250 & 250 & 299 & 255 & 320 & 320 & 277 & 268 \\
\hline
\end{tabular}

The decline in the number of students at private universities in East Timor in recent years has not only occurred at UNITAL but other private universities have also experienced the same decline. This decline in the number of students can create new problems for UNITAL and also other private universities because it will become a burden for universities to develop because the financial and financial components are the factors that determine the exact teaching and learning activities that are used, among others, for the costs of facilities and teaching equipment..

Reduction in funding caused poor service conditions, neglected building maintenance, and decreased academic quality. Student satisfaction becomes a reference for organizations to meet student needs so that they excel in sustainable competitiveness. Students choose the services of an organization to survive based on information from friends, family, service user institutions after comparing the services they experience with what is expected [4].

The decrease in the number of students can indicate that there are issues that must be taken seriously, the lack of facilities, human resources and quality of service and good relations with external in meeting the needs of students will become obstacles in the learning process, all the knowledge possessed by the leadership and staff in handling student data is not well documented or still tacit.

Handling the problem of student decline is done by having stakeholders who have gained a lot of knowledge (knowledge creating) and shared knowledge (knowledge sharing) within the university organization through evaluation meetings. Knowledge capture modeling will describe the problem situation, capture knowledge in the process, tacit knowledge pooling and the process of its application. expressing knowledge that was formerly a personal knowledge for each person will be a wealth of university organizations to strategically build in handling the decline of both prospective students and drop out students, and the capture of knowledge can utilize information technology [5].
From the description of the problems that have been raised, it is necessary to create knowledge in the process of handling the problem of reducing the number of students that can be documented so that it becomes a wealth of knowledge and can be utilized, then it can be applied in the concept of Knowledge Capture. Explore, elaborate and execute techniques will be applied as a method to capture the knowledge possessed by stakeholders, especially leaders and related parties who fight in handling student services. This three-way amalgamation technique becomes one to deal with the problem. Therefore, researchers will discuss this problem with the problem formulation "How to analyze the decrease in the number of students with Explore, Elaborate and Execute techniques"

\section{Method}

\section{a. The method used}

\section{1) Knowledge Management}

Knowledge Management is a collection of principles, processes, organizational structures and technology applications that help people share and improve knowledge to meet business goals in the organization through the application of information and communication technology so that it can be shared with all employees. In essence there are two main types of knowledge, namely tacit knowledge is the experience of every individual that involves several factors such as perspective, beliefs, experience and personal values, and tacit knowledge is difficult to transfer. While explicit knowledge is knowledge that can be transferred and created in books, data, newspapers, magazines. [6].

\section{2) Knowledge Management Component}

The most important components contained in KM are four, namely:

a) Human. Human knowledge management is the main actor in the process, and is also a source of knowledge management knowledge. 
b) Technology. As the main media for distributing knowledge and making it easier to use information and knowledge through technology.

c) Process. Is an activity that consists of capturing, filtering, validating, transforming, knowledge throughout the organization equipped with carrying out certain procedures and processes.

Content. It is information and knowledge along with documents needed by people in implementing their obligations in knowledge management.

3) Model Socialization, externalization, Combination, Internalization (SECI)

Converting two types of knowledge, namely tacit and explicit through four kinds of conversion processes namely SECI shown in Figure 1.

\begin{tabular}{c|c|c|}
\multicolumn{1}{c}{} & \multicolumn{1}{c}{ Tacit Knowledge } & \multicolumn{1}{c}{ Explicit Knowledge } \\
\cline { 2 - 3 } Tacit & Socialization & Externalization \\
\cline { 2 - 3 } $\begin{array}{c}\text { Knowledge } \\
\text { Explicit } \\
\text { Knowledge }\end{array}$ & Internalization & Combination \\
\cline { 2 - 3 } & \multicolumn{2}{|c|}{ Figure 1: SECI Model }
\end{tabular}

a) Socialization is the process of sharing and creating tacit knowledge through direct interaction and experience from individual to individual.

b) Externalization is the articulation of tacit knowledge into explicit knowledge through a process of dialogue and reflection, tacit knowledge in a more general form so that it can be understood by other people's explicit knowledge.

c) Combination is the explicit conversion of knowledge into more subsets.

d) Complex through systematics and the application of explicit information and knowledge from groups to organizations.

e) Internalization is the conversion of explicit knowledgeinto tacit knowledgeoforganizational members, which is spread throughout the organization through its own experience, so that it becomes new tacit knowledge from the organization to individuals. [7].

Research conducted by Ammar A. Ali Zwain et al., That in this information age mentioned that almost all organizations are driven by knowledge to achieve or maintain competitive advantage. KM in education can be defined as a tool that gives instructions to managers and staff in organizations. KM helps educational organizations to realize the advantages and beauty of creating knowledge sharing as a means to improve teaching and learning.
Because higher education is currently subject to market pressures that are required to make big changes to compete. Universities think like business to the point that students are now treated as customers, so Universities have the responsibility to produce graduates who are able to accommodate challenges that arise in society, such as producing high-quality graduate profiles and competencies in their respective professions [8].

\section{4) Knowledge Capture}

Capturing knowledge is the process of thinking of an expert that can be captured properly. To produce knowledge management, a knowledge management application maker can work together with the relevant experts to translate it into a pre-programmed application.

Research conducted by Silwattananusarn and Tuamsu, namely that data mining in developments in business organizations there are four findings in this study. Knowledge sources, knowledge types, knowledge datasets, data development tasks, and data development applications used in knowledge management. Can conclude in an organization, knowledge is an important resource. Knowledge resource management has become a strong demand for development and finding useful knowledge and also management in decision making [9].

\section{5) Customer Satisfaction}

Consumer satisfaction is the main goal of every company. Universities as institutions that provide educational services to students, therefore must uphold student satisfaction as a way to retain students as consumers, subjective evaluation of students from what is felt and this experience will be formed in a sustainable manner in everyday life in the relevant university environment with education. For companies engaged in customers, it can cause consumer dissatisfaction with disappointment, anger, and protest so that consumers can leave the company, while customer satisfaction can increase company profits and create consumer loyalty to the company [10]. According to Kotler 2000, service quality is the basis for service marketing, because the core product being marketed is performance (quality), and performance is purchased by customers, therefore service quality performance is the basis for service marketing. The concept of good service will provide opportunities for companies to compete in winning consumers. While the good performance (quality) of a service concept creates a competitive situation where it can be implemented through strategies to convince customers, strengthen the image of sales and pricing [11].

\section{6) Explore, Elaborate, and Execute}

Exploration is the first step in increasing understanding and building knowledge through a phenomenon, so in this exploration cycle to build their own knowledge of the stimuli obtained, exploration activities do not only focus on what is found but arrive at the process of knowledge 
excavation that is somehow related to the previous material or information is completely new. Elaborate is the actualization of various meaningful activities and works from a series of activities. Elaboration means completion and diligence and execution is the application or implementation. execution are some of the methods commonly used in conducting research [12].

\section{b. Research Phase}

This research is a qualitative research with the model used is knowledge capture with techniques. Explore (exploration), Elaborate (elaboration), and Execute (execution). Data collection is done by means of, observation, interviews, documentation and questionnaires. The problem solving process uses steps, i.e.

1. Case Study Analysis Phase,

2. Knowledge Capture Modeling Phase

The following is an illustration of the problem solving process as shown in Figure 2.

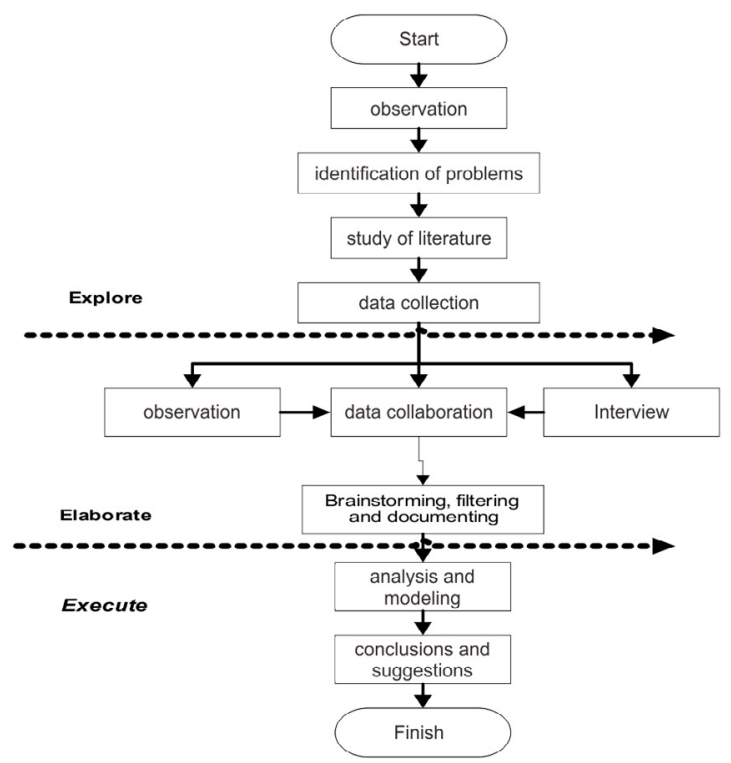

Figure 2. Framework for Resolving Problems [5]

In this study there are several processes to solve the problem, namely the exploration process, the analysis process and the knowledge capture modeling process. The researcher began by observing at the UNITAL research location to identify problems related to the decrease in the number of students and to see firsthand all the activities carried out by the actors. After making observations, it can be identified on several things that cause a decrease in the number of students and can also identify that the number of students decreased significantly from the last four years.

Interviews were conducted to find out the tacit knowledge that was known by the actors in handling the problem of decreasing the number of students. Interviews were conducted by the chancellor, vice chancellor (WR), deans, study program heads, lecturers, and students as service users who needed to be captured. From the capture of this knowledge the researchers initially conducted a study of related literature so that the results of the research could become credible scientific work. Data collection through observation and interviews and then data is collaborated to find out what causes the decrease in the number of students that occur each year. In the exploration stage is the initial stage of processing data that has been collected through collecting data, elaborate is resistant to data collection by actualizing the data collected, the execute stage is comparing brainstorming information, documenting that is done with actors to produce models in knowledge capture.

\section{Knowledge Capture Model}

In dealing with the problem of decreasing the number of students from Explore, Elaborate and Execute techniques, a new model of knowledge creating is formed, the process of final execution, arrest has resulted in explicit knowledge of the actors. Illustrated in Figure 3.

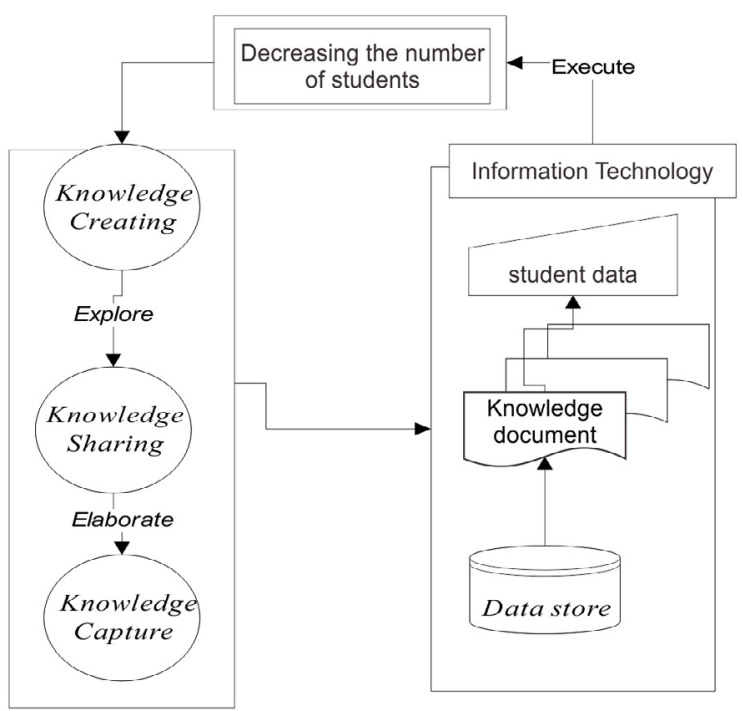

Figure 3. Knowledge Capture Model

The method applied in problem solving is to capture the knowledge associated with a decrease in the number of students using explore, elaborate, and execute techniques. During dealing with the problem, a knowledge creating by the actor was formed, where the capture of knowledge by exploring technique was carried out to find the cause of the decrease in the number of students and the knowledge of the actors regarding the decrease in the number of students.

During the process that was passed, in the course of this handling a tacit knowledge was formed that had not yet been structured and stored. That knowledge should be stored as the wealth of the organization to increase knowledge in decision making for the future. To be more structured, efficient and meaningful, knowledge must be shared by conducting elaboration techniques through knowledge sharing to accommodate all tacit knowledge from superiors, lecturers, employees and technicians, then filtering and documenting more structured. 
The results of elaborate as a knowledge capture to be stored in a database are used to help the processing of knowledge with the help of information technology. The knowledge captured in the form of stored knowledge documents is a wealth of organization that always pays attention to the quality of service to students. This is also to anticipate a decrease in the number of students and to strive for prospective new students and active students who have gone on to survive to complete their education.

\section{Results}

In the field research, several causes can be identified to decrease the number of students, both new students who register and also active students who drop out every year. Based on observations and interviews conducted with the chancellor, WR, deans, program leaders, lecturers and students as the main actors in the academic process. The following are the results of the interview:

\section{a. Interview Results Data}

Table 3: Results of the Rector and WR Interviews, Deans, Study Program Heads and Lecturers.

\begin{tabular}{ll}
\hline & \multicolumn{1}{c}{ Factors That Affect Student Declines } \\
\hline Rector & $\begin{array}{l}\text { Professional attitude, friendliness, empathy, and respect for students by lecturers, employees, } \\
\text { and technicians. The financial system is in the form of burdensome increases and dispensations. } \\
\text { Academic hospitality for filling in and compiling KHS and KRS, distributing and recapitulating } \\
\text { active and inactive student lecturer data, facilitating examinations, documenting alumni, library } \\
\text { management, and laboratories. the recruitment of lecturers, staff, and technicians does not meet } \\
\text { the standard operating procedures (SOP) }\end{array}$ \\
Vice & $\begin{array}{l}\text { Domestic government political policy, institutional competition with facilities provided by other } \\
\text { private state universities, the supply of physical facilities such as buildings, classrooms, tables, } \\
\text { chairs, and furniture to provide security and comfort, public facilities and infrastructure. The } \\
\text { academic system operates easily understood and easy to implement, clarity of information, and } \\
\text { guarantee the confidentiality of information. }\end{array}$ \\
Dean & $\begin{array}{l}\text { Promotional services to the public with an updated, safe and credible web information system, } \\
\text { providing services to complaints from students and the public. Location and public transportation } \\
\text { facilities that access UNITAL. } \\
\text { The value of study program accreditation and curriculum renewal in accordance with the changing } \\
\text { times. The environment around the building is clean, ensuring student comfort, and managing } \\
\text { parking in an orderly and safe manner. } \\
\text { the study } \\
\text { program } \\
\text { Lecturer }\end{array} \quad \begin{array}{l}\text { Availability of public facilities, computer standards in the laboratory, collection of books provided } \\
\text { in the library, availability of free internet for students, e-library system. }\end{array}$ \\
&
\end{tabular}

\section{b. Student Interview Data}

Table 4: Student Interview Results

\begin{tabular}{cl}
\hline Student & \multicolumn{1}{c}{ Student Dissatisfied } \\
\hline & Timeliness of service to students for validation of SPP receipts, Community \\
& Guidance by custodian lecturers, faculty physical buildings and study programs \\
& with other supporting facilities. A careful and cooperative administrative system. \\
& The presence of lecturers provides courses, thesis guidance, modules used when \\
& giving lectures. Free Wifi for students, lecturers, employees, laboratory availability \\
& according to lecture needs. \\
Student & Clarity of information Employees to students, lecturers are ready to help students \\
& if needed, other programs that encourage students to be creative in improving \\
& abilities, such as: seminars, workshops, sports, dance, music. Friendliness of \\
& employees in serving students, understanding material by students when attending \\
& lectures. The method used by the lecturer can make it easier for students and \\
& lecturers to master the material taught, academic administration hours, finance, \\
and faculties that are in accordance with student needs. & Using information technology in the learning process and other information \\
student & services, strategic location of the campus, library clerk working hours in \\
& accordance with the specified working hours, friendliness, willing to help when \\
& needing, explaining the book search system, information clarity, using information \\
systems to manage the library. improve computers and other practical tools in the \\
laboratory.
\end{tabular}




\section{c. Observation Data}

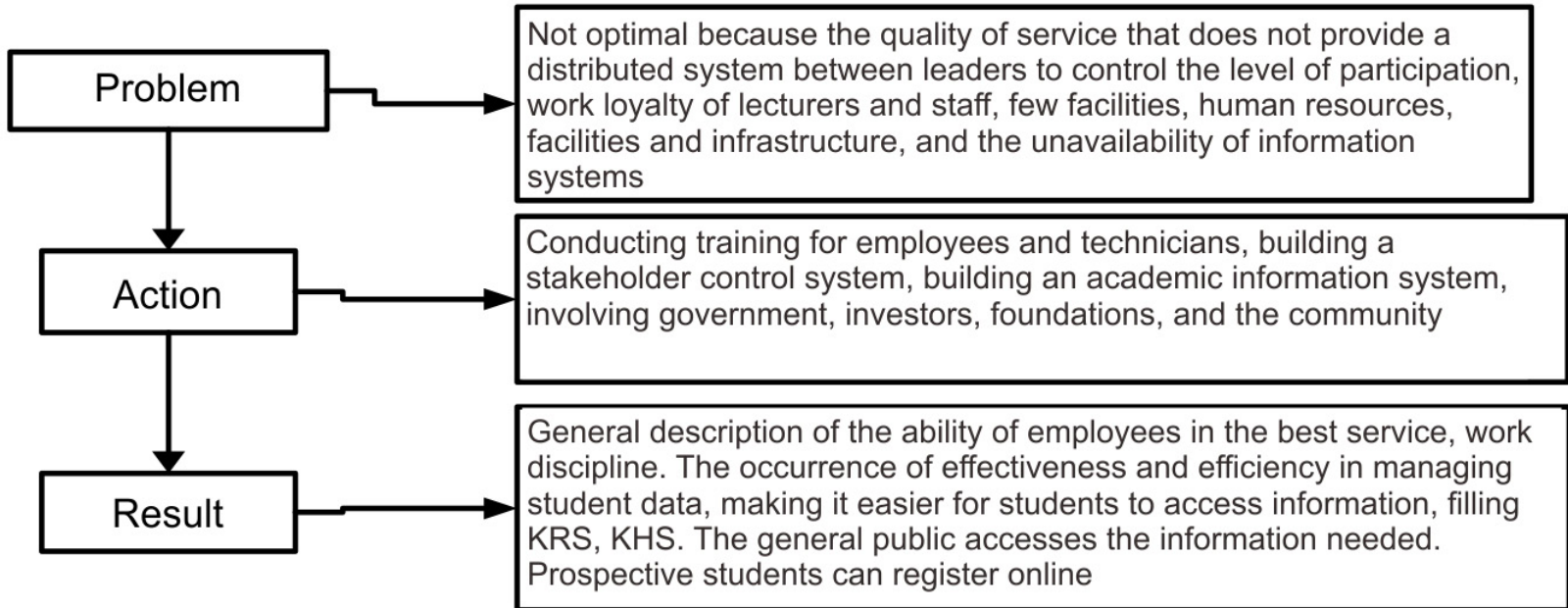

Figure 4. Thinking Framework for Observation Data

From observations made that internal and also external factors that influence so that problems arise in the decline of students. The learning process especially UNITAL is currently not optimal, namely the quality of services provided to students, due to the absence of a distributed system between superiors to control their subordinates so that the current human resources do not maximize their skills to build each faculty and study program, lack of participation rates, work loyalty of lecturers and employees and technicians. Besides that, from facilities, human resources (HR) facilities and infrastructure and information systems are a series of interrelated activities and are not separated from each other, if one is abandoned then the learning process cannot run properly so that learning objectives cannot be achieved. The lack of institutional collaboration with other universities both domestically and abroad, companies, non-government organizations and the community. After making observations and taking and researchers want to examine more deeply. Here is a framework for thinking from research conducted by researchers.

\section{d. Brainstorming}

Tacit Knowledge is knowledge that is rooted in one's actions and experiences so that the knowledge possessed by the individual is still categorized as intuition and conjecture [13]. To document the knowledge of tacit into explicit is by brainstorming. The brainstorming stage is as shown below.

The process of data retrieval using brainstorming techniques is an effort to extract the contents of the knowledge possessed by actors which encourages the emergence of many good ideas, bad ideas, criticisms, suggestions and creative ideas and then documents all the knowledge in the form of tacit related to the problem of decreasing the number of students. Braingstorming produces a document which is then filtered and selected as tacit knowledge related to the material, after filtering that knowledge to be applied in the knowledge of each tacit.

Table 5. Brainstorming Results

\begin{tabular}{ll}
\hline Actor & \multicolumn{1}{c}{ Knowledge } \\
\hline & $\begin{array}{l}\text { Responsive staff lecturers, and technicians are } \\
\text { willing to help and have the capacity to solve }\end{array}$ \\
Actor 1 1 & $\begin{array}{l}\text { urgent problems, employees have the capacity to } \\
\text { solve problems, and respond to student complaints } \\
\text { responsibly. }\end{array}$
\end{tabular}

Guaranteed universality in service to students who are friendly, polite. The university's responsibility

Actor 2 to provide information technology systems to facilitate both managing research, managing grades, student data, lecturers, staff and other resources, promotion information, which is effective and safe.

Academic elements such as: qualifications and professional lecturers, staff, and technicians, development planning and creativity in study

Actor 3 programs, curriculum, instructions from superiors regarding methods, synchronizing assessments and evaluations for students, university financial management with transparency systems.

The academic department plans, accreditation programs, graduations, access for alumni,

Actor 4 outside parties concerned. Striving for a campus atmosphere that provides comfort, campus clinics, student counseling services.

\section{c. Problem Analysis Schema}

Based on the results of interviews, observations, documentation and brainstorming can be found above then do an analysis of the consequences, reasons, and field conditions that have been carried out as follows: 


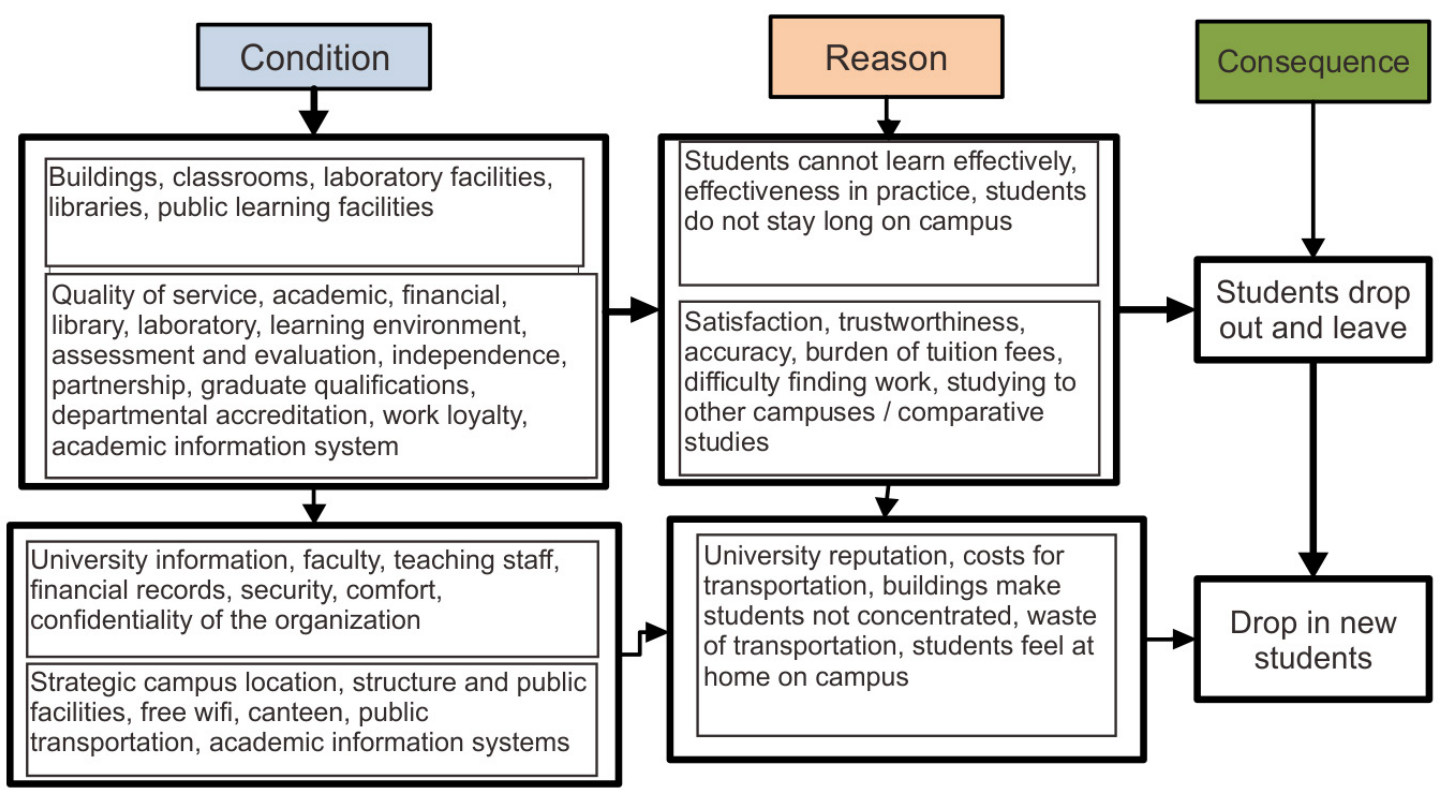

Figure 5. Schematic Analysis of Problems

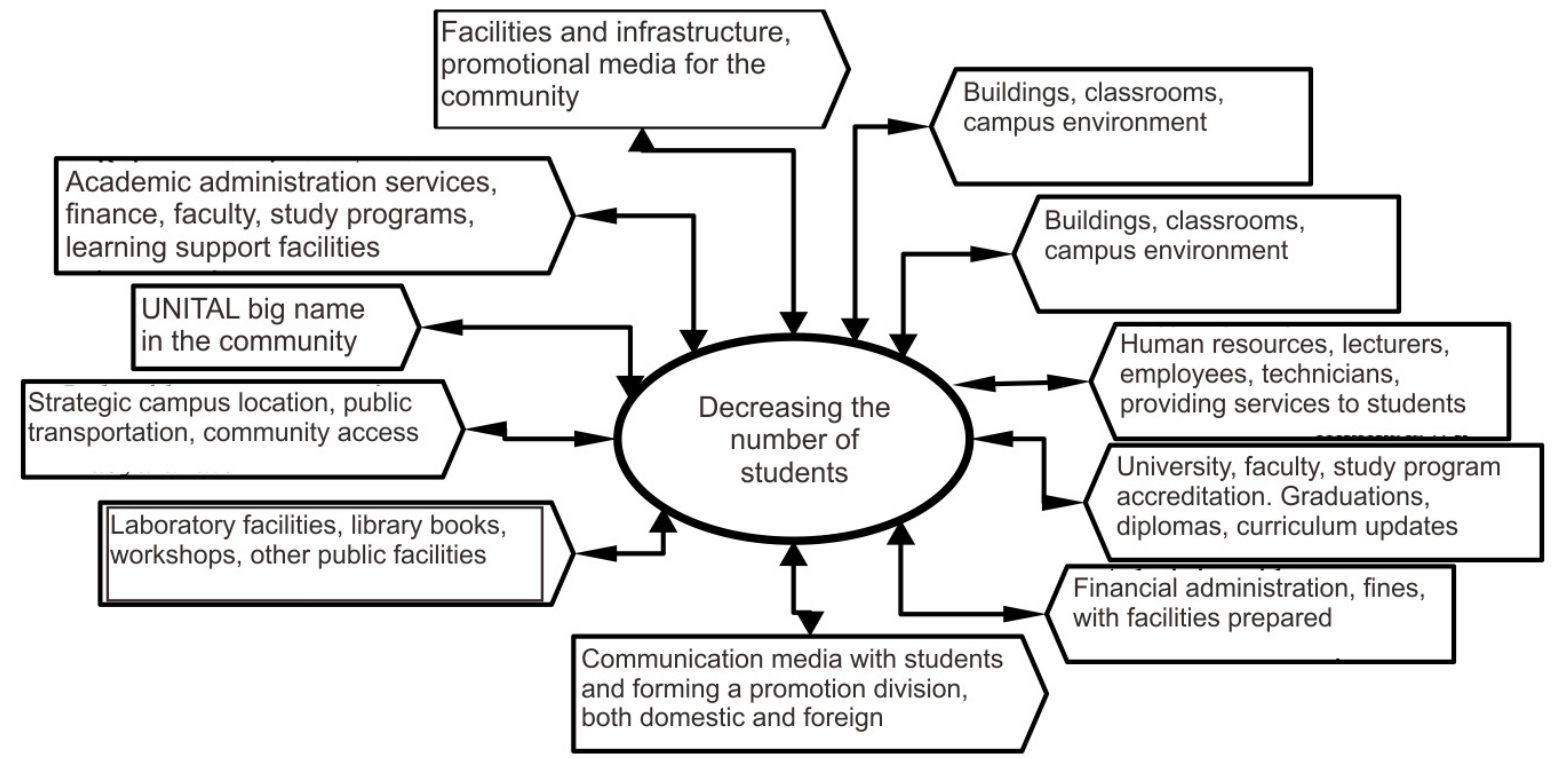

Figure 6. Causes of Student Decline

In the scheme above it can be found the cause of the decline in students due to several reasons such as the big name of UNITAL in the community, the safety and comfort of students during college, the strategic location of the campus. Other causes of the decline in active students who drop out are the lack of facilities to support the teaching and learning process, such as classrooms and furnishings, availability of facilities and infrastructure for students, laboratories and student practice hours, availability of books in the library, professionalism in academic services, HR (lecturers, employees and technicians), a campus atmosphere that provides student comfort, accreditation of study programs.

\section{d. Explore}

With the Explore data interview technique, observation and documentation conducted can show that there is indeed a very significant decrease in the number of students, from the knowledge captured, it can be identified that there are various reasons as a cause of the decrease in the number of students shown in Figure 6.

The decrease in the number of students each year, both prospective new students who want to register and active students who drop out are obstacles to the learning process. The causes of the decrease in students are internal management factors, facilities, facilities and infrastructure for students, lecturers and staff, books and library furniture, workshop laboratories for practice, studios, clinics, faculty building construction, strategic locations for public transportation access, political stability in country, HR factor, communication media to bridge students with academics as a credible promotion media, study program accreditation, UNITAL good name. The external factor is cooperation with other universities both 
domestically and abroad, government institutions and the community.

\section{e. Elaborate}

To solve the problem in accordance with the elaboration of the framework in solving the problem at this elaboration stage can collaborate between four stages of research carried out namely Observation data collaboration, interview, brainstorming and documenting. The final result of the collaboration of observation and interview data obtained is the result of a discussion of a decrease in the number of students, namely exploration. From the data collected from the interview, the services provided to students are from the attitude of friendliness, clarity of information, certainty of information from lecturers, staff and technicians, the supply of special and public facilities such as laboratories, books and furniture in the library, buildings that have not been evenly distributed as a whole. all faculties.

The absence of an academic information system to provide accurate and up to date information to students and the public, the lack of human resources, and government politics. Observations, which are carried out to be able to observe directly that the decline in students can be caused by the convenience of students while on campus, the attitudes and loyalty of lecturers to work, time discipline, lack of a system to control all lecturers, employees and technicians, the lack of cooperation between universities, government and private institutions both inside and outside the country to conduct training for lecturers, staff and technicians. Brainstoring, accuracy of information held by lecturers, staff and technicians, because information is not centralized, qualifications and professional lecturers, staff, and technicians, development planning and creativity in study programs, curriculum, synchronization of assessments and evaluations for students, financial management of universities with systems transparency, information technology to facilitate both managing research, managing grades, data of students, lecturers, staff and other resources, promotion information, which is effective, and information that guarantees its safety.

Documentary, from the documentation can show that the decline in students occurs every year, and field conditions occur lack of facilities both public facilities, both physical and non-physical facilities.

The elaboration process is the result obtained based on the results of exploration, the material contained in this elaboration process is about the problem of decreasing the number of students. The question is why there is a decrease in the number of students not only for prospective new students but also for active students who drop out and leave and are no longer active. From the data in the field can show several problems and as a solution to the problem. This problem concerns the decrease in the number of new students enrolled and active students dropping out. This problem and the internal factors caused by external factors can be explained in Figure 7.

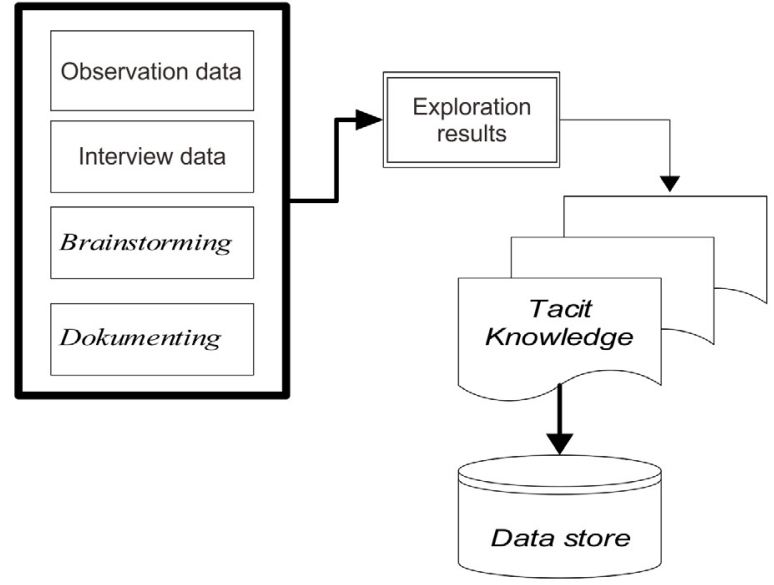

Figure 7. Elaboration Process

After finding material in the elaboration process, brainstorming with actors is carried out to gain the knowledge and experience they have regarding the problem of decreasing the number of students, the amount of experience they have is in accordance with the material prepared at the beginning.

\section{f. Execute}

This process is the third stage of the explore and elaborate process or the final stage can be illustrated in Figure 8.

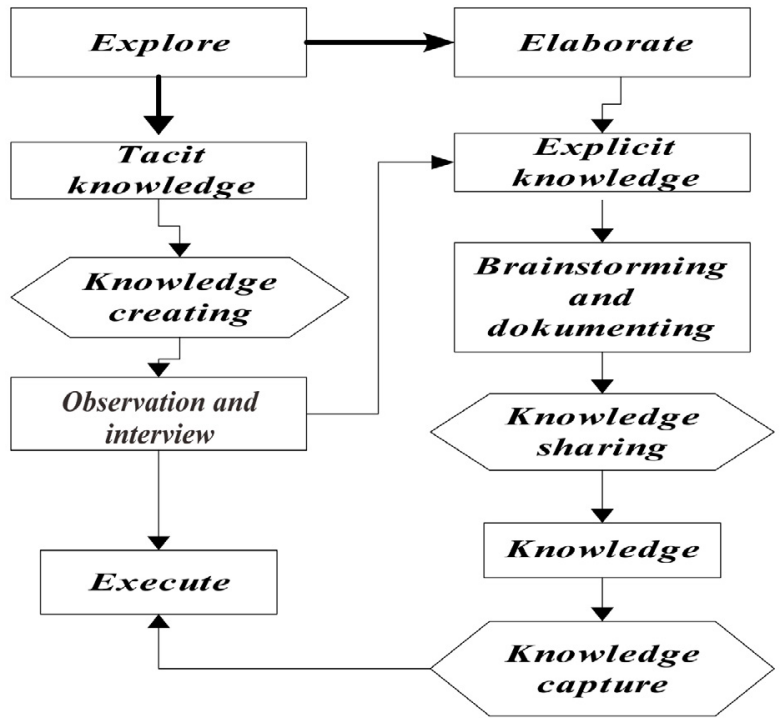

Figure 8. The execute process

The process of exploring and elaborating is done with the results obtained is that the material contained contains a decrease in the number of students. The process of exploration results obtained from data collaboration, observation and interviews which are the result of discussion of the problem of decreasing the number of students and elaborating data on Brainstorming and Documenting. The execute process is the last stage of knowledge capture techniques based on explore and elaborate techniques that produce explicit knowledge from actors. 


\section{g. Proposed Solution}

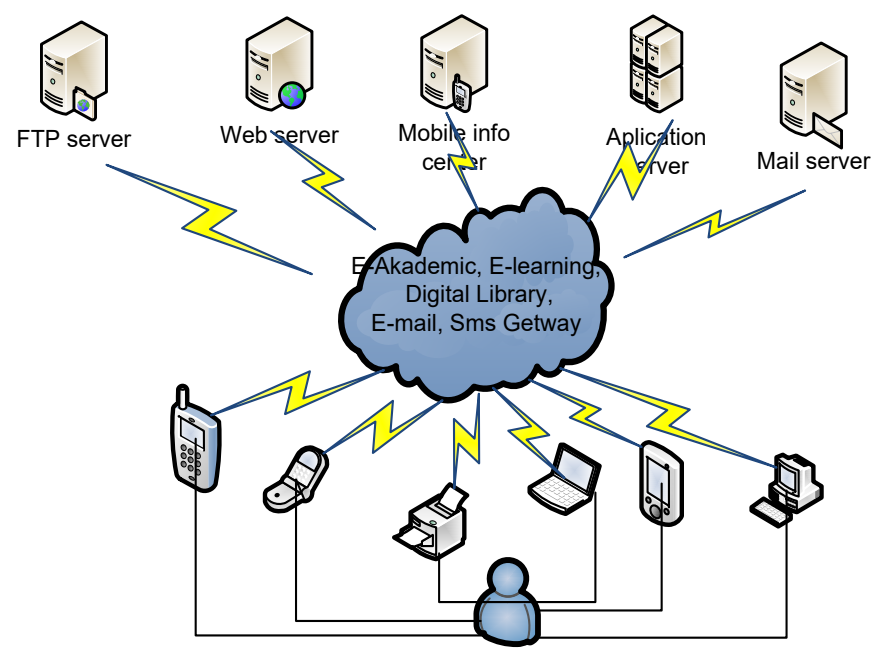

Figure 9. Concept of UNITAL Digital Campus

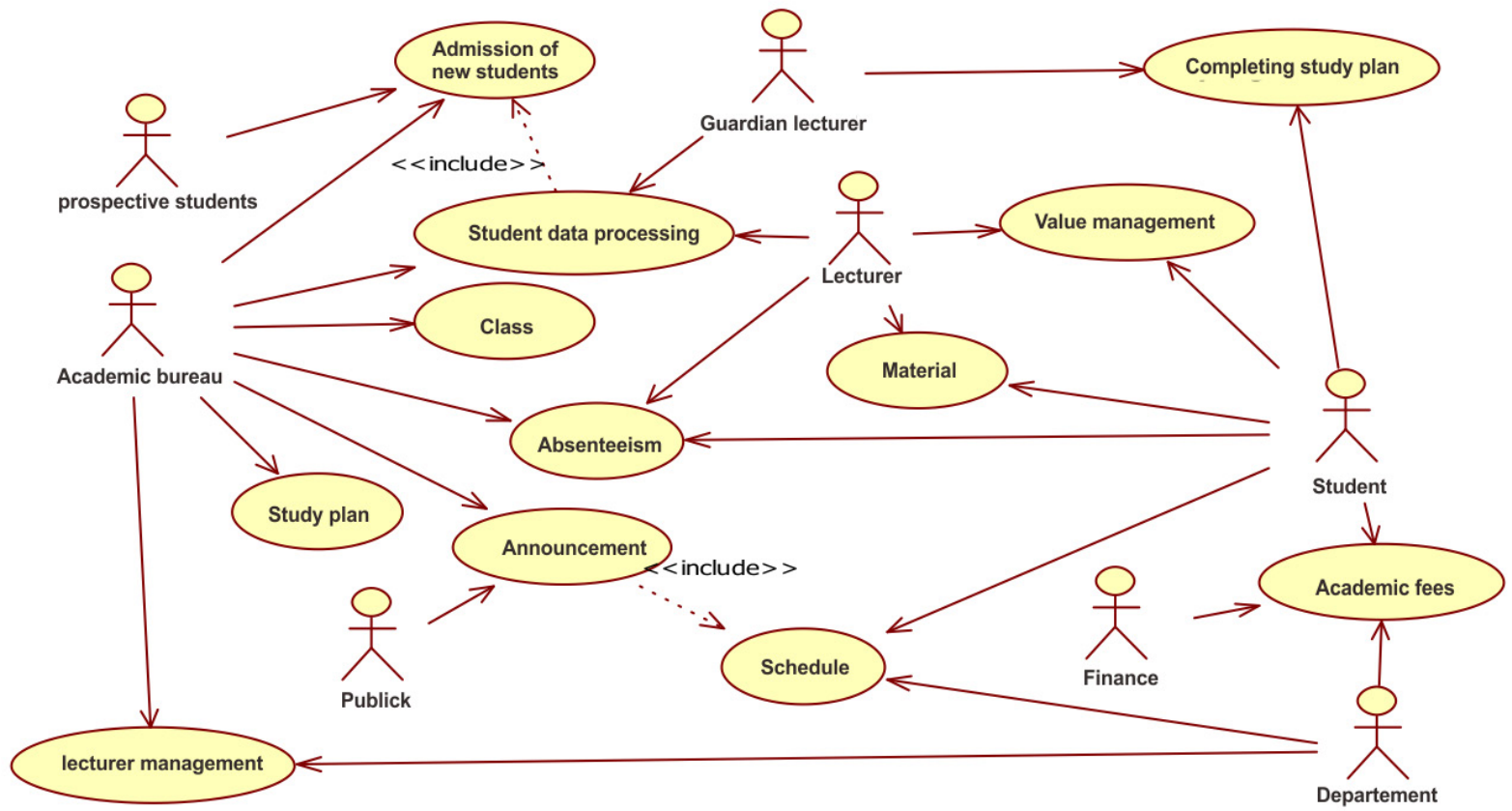

Figure 10. (Use Case) of the Academic System Proposed

The decrease in the number of students is the responsibility of all stakeholders. With competition in the world of education especially private universities becoming increasingly fierce, stakeholders are required to have strong intellectual capital and adhere to a system that is open to all and responds to all the desires and needs of effective and efficient stakeholders, especially for students and the community. Organizational structure must encourage the creation of a creative, innovative and efficient intellectual learning culture in the process of sharing knowledge between individuals so that they realize and understand their overall role. UNITAL is able to compete and even win the competition if it is able to offer quality products or value-added services desired by students and the community. The solution is to use Knowledge Management System (KMS) that refers to innovative technologies such as the internet, extranets, and data warehouses to facilitate and facilitate KM communication between inside and out.

The concept of digital-based campus will not be separated from supporting components such as the internet, computers, and websites. Digital campus will emphasize more services, namely the management of education administration that is effective and efficient. Online-based Student Information Systems will be a new way of recording transaction management and processing that is efficient in processing student information and will 
help for administrative staff, academic staff, grant providers or stakeholders, and can also produce student data [14].

Supporting factors for the achievement of Information Systems Technology infrastructure such as academic web, sms center, mobile access, e-mail, e-learning and e-library. Internet network inventory will be able to facilitate users in accessing information through various devices such as laptops, computers, phones and tabs.

The schema below can illustrate that to meet the needs of students in computerized services and can improve performance in the service of quality human resources and improve competitiveness, academic information is needed in managing student grades, management data of faculties / majors, teaching staff data (lecturers) and also other relevant information. With the information system, BAAK can facilitate the management of student data, dosages, employees, KRS, announcements, attendance management, PMB registration, class management. Lecturers can access teaching schedules, KSR guidance, filling material, filling student grades. The finance department can carry out financial management with academic well. Students can access lecture schedule information on grades, lecture material and other academic information. Prospective students can access PMB information, information about public campus facilities and register online. The general public can access information about UNITAL in general. Implementation of information systems with $\mathrm{KM}$, then an organizational and individual process becomes easily coordinated and systematic. Technology can provide added value through innovation thinking. And through Information Technology all knowledge can be inclusive and elaborated to develop short-term, medium-term and long-term strategies [15]. The proposed network scheme is shown in Figure 11.

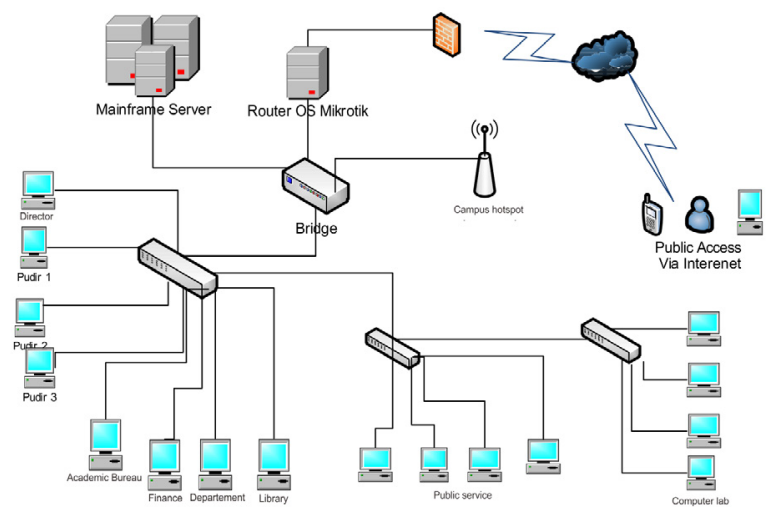

Figure 11. Proposed Overall Network Schema

\section{Conclusion}

To handle the case of the decline in the number of students, the chancellor, vice chancellor (WK) chancellor and lecturer, and employees already have Knowledge creating, as shared knowledge while in UNITAL.

In knowledge sharing through evaluation meetings at the rector and faculty level, knowledge is not captured to make important documents for the organization to be used in decision making. By using knowledge capture methods and explore, elaborate and execute techniques, it has succeeded in describing the conditions of the problem, the process of capturing knowledge and the process of pooling knowledge..

It is recommended for universities to improve the responsiveness of management to provide services to student complaints, seek regular training to all staff, technicians and educators. Building information systems that provide information, leadership, management systems, quality assurance, students and graduates, human resources, curriculum, academic atmosphere, financing, facilities and infrastructure, research information systems, community service, cooperation and Information Technology services.

\section{References}

[1] Retnoningsih Endang, "Knowledge management system (kms) dalam meningkatkan inovasi lppm perguruan tinggi”,Evolusi Vol. I No.1. 2013

[2] Rinala Nyoman, Yudana Made., et al. "Pengaruh kualitas pelayanan akademik terhadap kepuasan dan loyalitas mahasiswa pada sekolah tinggi pariwisata nusa dua bali”, program pascasarjana universitas pendidikan ganesha. Program studi administrasi pendidikan. Vol 4, No 1 (2013). 2013

[3] Shifia Amna Aulia, wiwik. "Analisis kepuasan mahasiswa terhadap layanan akademik di institusi xyz" Jurnal Teknik dan Ilmu Komputer, Vol. 05 No. 18, Apr - Jun 2016.

[4] Sumarno, Efendi Ahmad. "Dampak Biaya Kuliah Tunggal Terhadap Kualitas Layanan Pendidikan. Jurnal manajemen pendidikan”, Magister Manajemen Pendidikan, FKIP Universitas Kristen Satya Wacana, e-ISSN 2549-9661, Volume: 4, No. 2, Juli-Desember 2017.

[5] Victor, Manongga, et al. "Knowledge capture menggunakan teknik explore, elaborate dan execute untuk bagian kesiswaan sekolah", jurnal informatika jurnal pengembangan IT(JPIT) vol 03, no. 03 september 2018, DOI: 10.30591/ Jpit. V313.1002. 2018

[6] Iskandar, tony. "Perancangan knowledge management system pada it bina nusantara menggunakan blog, wiki, forum dan document", Computer Science Department, School of Computer Science, Binus University, ComTech Vol. 5 No. 1 Juni 2014: 110-122. 2014

[7] Smith and lyles. Handbook organization learning annd knowledge management. The Atrium, Southern Gate, Chichester, West Sussex, PO19 8SQ, United Kingdom. 2014

[8] Ammar A. Ali Zwain. "Knowledge Management 
Processes and Academic" Performance in Iraqi HEIs: An Empirical Investigation, International Journal of Academic Research in Business and Social Sciences June 2012, Vol. 2, No. 6 ISSN: 2222-6990.

[9] Silwattananusarn Tipawan, Tuamsuk Kulthida. "Data Mining and Its Applications for knowledge Management" Khon Kaen University, Thailand Vol.2, No.5, September 2012 DOI : 10.5121/ ijdkp.2012.2502 13.2012

[10] Ina ratnasari. Pengaruh kualitas pelayanan dan citra institusi terhadap kepuasan mahasiswa yang berdampak pada word of mouth (studi kasus pada mahasiswa universitas singaperbangsa karawang.. Value Journal of Management and Business, ISSN 2541-397X, Vol. 1 No. 1 Oktober 2016.

[11] Kotler philip. Maketing management the millenium edition. Ten edition. USA: prenticehall,inc.) 2000

[12] Pramono, Nia Ariani. "Kemampuan Guru Melaksanakan Kegiatan Eksplorasi, Elaborasi dan Konfirmasi dalam Pembelajaran Bahasa Indonesia SD Negeri 182/I Hutan Lindung”. 2018.

[13] Karto iskandar; tony; claudia henlly phankova; wongso agustino "Perancangan knowledge management system pada it bina nusantara menggunakan blog, wiki, forum dan document" Computer Science Department, School of Computer Science, Binus University ComTech Vol. 5 No. 1 Juni 2014: 110-122 no 5).

[14] Eileen Bayangan-Cosidon. "Student Information System for Kalinga State University-Rizal Campus". International Journal of Management and Commerce Innovations ISSN 2348-7585 (Online) Vol. 4, Issue 1, pp: (330-335), Month: April 2016 - September 2016.

[15] Muhammad Jawad Iqbal, Amran Rasli, at., el.. "Academic staff knowledge sharing intentions and university innovation capability Vol.5 (27), pp. 11051-11059.2011 